\title{
Food, Global Environmental Change and Health: EcoHealth to the Rescue?
}

\author{
David Waltner-Toews*
}

Everything is changing, and changing rapidly, except how we think.

What we eat brings issues of health and global environmental change to the table in ways that are urgent, global, and full of scientific uncertainty. Eating is the most intimate relationship we have with the environment, when various parts of plants and animals are integrated into our bodies. Our eating habits link human nutrition (and all the health issues associated with that) and infectious foodborne diseases to agricultural practices, land use, global trade, poverty, economic inequity and climate change.

Official estimates of the incidence of endemic foodborne diseases (as differentiated from outbreaks) from both Canada and the United States show that there were increasing trends from the 1970s to the late 1980s and 1990s. This was the period when Western industrialized countries saw the emergence of new variant Creutzfeldt-Jakob Disease associated with bovine spongiform encephalopathy, serious diseases caused by shiga-toxin-producing E. coli, the pandemic of Salmonella enteritidis and the recognition of listeriosis as a foodborne illness. While one can pinpoint specific causal pathways for each of the diseases, they all reflect more general systemic and cultural changes, including population growth and mobility, a huge shift in agriculture to economies of scale and mass distribution, land use changes including manure production by large livestock enterprises, an expectation of low food costs at the grocery store, relatively low oil costs, better detection methods and a more alert public $(1,2)$.

The increases of the 1980s might be said to have culminated, at least in the public eye, in the 1993 deaths

*To whom correspondence should be addressed:

Dr. David Waltner-Toews

Ontario Veterinary College

University of Guelph

50 Stone road, RM 207A

Guelph, ON Canada

N1G ZW1

Email:dwaltner@ovc.uoguelph.ca of four children who succumbed to E. coli $0157: \mathrm{H} 7$ infection after eating hamburgers at a fast food restaurant. While this was not the biggest nor most spectacular outbreak of this disease, it coincided with the election of Bill Clinton to the White House, and a serious reworking of food safety procedures in the United States. This was followed by a drop in rates of foodborne infectious diseases for a few years about the turn of the new millennium, and then a settling in to relatively stable rates. The decreases since the turn of the new millennium are probably the result of food industry sobriety and seriousness in the face of more aggressive government regulation, food recalls, litigation, and a worried public. The relative stabilization of rates in the past few years may well reflect a bottom line, the disease costs built into the current structure of the agri-food industry. Indeed, there is now good evidence that global climate change is already increasing occurrences of both foodborne and waterborne diseases in North America, Europe and Australia $(3,4)$.

While the general trends suggest one large story, the particulars of outbreaks in the decade since 1998 are perhaps more telling. There have been repeated outbreaks attributed to Salmonella, E. coli and other enteric pathogens associated with fresh sprouts, almonds, jalapeño peppers, tomatoes, cantaloupe, spinach and lettuce. In other words, infections caused by bacteria normally found in vertebrates are now being transmitted in fresh fruits and vegetables. In the past, one might have attributed such occurrences to crosscontamination in the home, or in a restaurant. The widespread nature of the most recent outbreaks, however, tells a different story. Economies of scale and the fertilizer and water use associated with intensification of production in a few areas, such as California, have led to field conditions that often mimic the insides of warm-blooded animals, allowing bacteria to adapt, evolve and grow. The agri-food industry has kept prices low, in part, by relying on uneducated workers with minimal understanding of food safety 
issues, and few facilities to implement hygienic practices even if they were so inclined. Mass distribution has enabled widespread distribution of the contaminated produce. A warming climate has provided a more congenial environment for the bacteria to proliferate during distribution.

The dilemma is that low food prices in the store enable people on low incomes to have access to more food. This can be a good thing if it improves nutrition and general health status, which is the underlying public health argument in favour of economies of scale and widespread trade. The question nutritionists need to ask is whether the "cheap food" policies are in fact achieving these goals, or if they have become part of the problem (5). There is good evidence that the emergence and global spread of zoonoses - including avian influenza - are related to the same industrial economies of scale that produce more "cheap chicken" (6).

Worldwide, the situation becomes even more complex, and the emergence or increase of foodborne illnesses must be seen in the context of the resurgence of infectious diseases in general (7). Rapid urbanization and population growth have increased demand for meat protein, particularly chicken and pork. The impacts have been seen most dramatically in Southeast Asia, where the response has been a rapid and dramatic shift to economies of scale, but over a much shorter time period and in very different ecological and cultural contexts than in North America and Europe. In North America and Europe, given high investments in technology and health care, one might argue that the negative impacts of salmonellosis, campylobacteriosis, listeriosis and diseases associated with E. coli are the necessary and manageable costs of keeping cheap food on the grocery shelves. Given the collateral environmental and social damage caused by disappearance of small communities, climate change and landscape degradation, many investigators are not willing to concede that argument. In Southeast Asia and elsewhere the case is even less convincing. The increases in duck, poultry and pig production, and the movement of populations and animal production facilities into new landscapes, has led to the emergence of a variety of new infections, including avian influenza and Nipah virus (6).

Physicians who see a whole string of patients with diarrhea in a short time period might be forgiven for thinking that they are in the midst of an outbreak, or an epidemic. For an epidemiologist, the increasing frequency of reported foodborne disease outbreaks raises further questions: are we seeing an outbreak of outbreaks? If so, is there some systemic cause of this?

One of the biggest problems facing those trying to resolve these thorny issues has been a lack of coherent and appropriate research and policy tools. Several authors have attempted to reframe the agriculture-health issues in terms of complex systems analyses (8), but these analyses have to date had little impact on either agricultural policy or health disciplines. The scientific evidence is too fragmented to make anything other than broad inferences, and the policy trade-offs are far from clear (9).

In recent years, there has been an increasing documentation and recognition that the majority of emerging diseases are zoonotic in origin $(10,11)$, and that, at the very least, better communication and coordination among veterinary and medical practitioners is essential. The initial focus on zoonotic diseases reflects the fact that the research methods and management tools are available, the primary obstacle to progress being organization, communication and coordination between human and animal health professionals. Furthermore, there is a unified biomedical tradition to draw on, that stretches from Hippocrates, to Rudolf Virchow and Louis Pasteur, who did not recognize the boundaries between human and animal medicine, and environmental and social change; to William Osler, who was a member of both the McGill medical faculty and the Montreal Veterinary College; Calvin Schwabe, whose 1984 book, Veterinary Medicine and Human Health (12), is a classic in the field; and James Steele, who founded the first veterinary public health unit in the United States.

In this tradition of linking human and animal health, a "One Medicine" or "One Health" movement has emerged, with endorsements from various national and international medical and veterinary associations (see, for instance, www.onehealthinitiative.com and www.oneworldonehealth.org). However, resolution of "one health" problems requires at the very least that one addresses some of the most serious environmental implications of both the problem emergence (land use change leading to loss of the buffering effects of biological diversity and habitat change for disease vectors, changes in the probability of human-agent contact) and the solutions (manure run-off from livestock enterprises designed to improve protein intake by poor people) (13).

There is increasing recognition, then, that the problems of health, ecology and social changes are complex, and embedded in the structures and changes of social-ecological systems $(14,15)$. This is where "One World, One Health" runs into some serious theoretical and practical challenges. At present, these public assertions appear to be orphaned good ideas, destined to fall victim to a kind of naive sense of global warm feelings. They describe desirable outcomes, but no processes by which one might arrive there, and 
hence fall back on inappropriate methodologies. Health scientists have developed excellent methods for developing and testing diagnostics, for evidence-based treatment protocols, and epidemiological designs to tease apart individual risk factors for disease. But these methods were never intended to answer questions such as: How can one best improve human nutrition globally without putting the next generation in jeopardy through environmental and climate change? What are the appropriate policies to foster sustainable human wellbeing?

If the linear causal thinking of laboratory science and conventional epidemiology are inappropriate to answer complex questions in which health is embedded in complex social-ecological dynamics, where can we turn for help?

The answers come from some unlikely sources - the integration of management theories and practices, action research, richer understandings of social and biological ecology and complexity theories. Since the 1970s, when systems theories first became visible outside of the small group of scholars, there have been major innovations of theories of complexity and complex systems, and demonstrated improvements in understanding complex social-ecological phenomena $(14,15)$. With the remarkable exception of studies looking at health issues related to climate change, where complexity is difficult to avoid (16), and some in international agricultural development (17), very little of this integrative, non-traditional scholarship has found its way into the medical and epidemiological literature (18).

Much of the scholarly and practice literature that has taken the challenge of making "One Health" something more than a good idea can be described under the general title of ecosystem approaches to health, or ecohealth for short $(15,19,20)$. Ecohealth draws on the latest theories of social-ecological complexity and integrates it with publicly-engaged, policy-relevant science. Ecohealth approaches are thus participatory, systems-based approaches to understanding and promoting heath and wellbeing in the context of social and ecological interactions.

Ecohealth may be seen as a way to address, simultaneously, the Millennium Development Goals (http://www.un.org/millenniumgoals/) and the Millennium Ecosystem Assessment (http://www.millenniumassessment.org/en/index.aspx). Indeed, the latter explicitly framed many of its results in terms of complexity and resilience theories. EcoHealth is also the official name of the journal of the International Association for Ecology and Health, and of a major Program Initiative of the International Development Research Centre.
Ecohealth approaches embed a variety of methodological techniques into a coherent, transparent, publicly engaged process of learning, monitoring, and learning again (methodological pluralism). In some ways, it is not so different from what a good clinician does when she integrates a patient history with clinical examination, epidemiological probabilities and laboratory test results to arrive at a reasonable diagnostic conclusion and course of action. Where it differs from clinical medicine is that the boundaries of the patient (Household? Community? Watershed? Globe?), the ownership of the "body", the nature of the complaint (one person's solution is another's problem), the relevant facts in a case, the systemic connections, and the most desirable outcomes are all in dispute.

While these sound like impossible challenges to overcome, they are not. Ecohealth has so far been most successful in situations where the boundaries, stakeholders and desirable outcomes are most apparent. These are often situations where dramatic infectious or toxic outcomes make certain courses of action sufficiently compelling to overcome institutional or individual stakeholder objections. Even in more messy situations, however, where the boundaries are uncertain and there are interactions across multiple scales of policy and practice, various methodologies and guiding questions are being used that are proving to be effective. There is even a sound philosophical basis, emerging from the risk assessment literature, for how the scientific inquiry can (and must) be changed in order to address these questions $(15,21)$.

This is the cutting edge of public health scholarship and practice. In keeping with its own underlying philosophy and theory, expertise in ecohealth is distributed and networked, rather than residing in particular disciplines or places. There is no critical mass in any one place and, given the dramatically increasing climatic, environmental, and socio-economic instability globally, the focus is on adaptability and the ability to shift and share information, resources and expertise across institutional, disciplinary and national boundaries as rapidly as possible. One of the earliest models for this has been the rapid growth of Promed worldwide (www.promedmail.org), from a small electronic network of interested practitioners to a global network of people working with infectious diseases that detects, tracks and responds quickly to emerging disease signals worldwide.

More recently, and encompassing issues well beyond emerging diseases, we have seen the emergence of Communities of Practice for Ecosystem Approaches to Health (CoPEHs); there are now such networked communities for Latin America and the Caribbean; South and Southeast Asia; Middle East and North 
Africa; West and Central Africa; and Canada (see Appendix for websites).

These communities of practice have been started by a variety of scholars and practitioners across a wide range of institutions and disciplines. The CoPEH in South and Southest Asia, which focuses on emerging infectious diseases, was started and is being maintained by Veterinarians without Borders/ Vétérinaires sans Frontières - Canada, with technical assistance from Google.org, and financial aid from the Canadian Food Inspection Agency, the International Development Research Centre, and private donors. Members include individuals and groups from governmental, nongovernmental, and trans-national organizations, as well as universities.

The Canadian CoPEH has as its primary objective the promotion and support of research, education, policy and practice in ecosystem approaches to health. Funded by the International Development Research Centre (IDRC), it is directed and administered by a consortium of Canadian universities (University of British Columbia, University of Guelph and Université du Québec à Montréal UQAM). Founding members range from physicians, such as the Head of Family Medicine at $\mathrm{UBC}$, to veterinarians, biologists, philosophers and communications experts.

As part of the educational mandate of this initiative, CoPEH-Canada has created an intensive short course entitled Ecosystem Approaches to Health. In 2008, the course was held in Vancouver at the University of British Columbia. In 2009, it is being held at the University of Guelph; and in 2010 at UQAM. In all cases students are recruited from across Canada and screened by senior members of the CoPEH.

The collapse of the post World War II global economic order, as well as the reorganization of the global climate system, is explainable through an understanding of complex system dynamics. Indeed such collapses and reorganizations are predictable moments in the lives of all systems, although their timing and extent can be modified and altered by human activities - as they have been both economically and climatically. What is of greater interest and urgency, however, is that these same understandings of complexity suggest that we are now at a point of unprecedented opportunity - and a challenge - to reorganize social-ecological relationships in a way that will nurture a sustainable, healthy, human population in a sustainable, healthy planet. Ecohealth offers new and exciting alternatives to understanding and managing changing patterns of foodborne and waterborne diseases in their social, agricultural and economic trading system contexts. This is not a challenge that can be met using more of the same techniques, organizations and lines of inquiry that have brought us to where we are. It requires new ways of thinking, new ways of acquiring and sharing knowledge, and new communities of practice.

\author{
APPENDIX: \\ Communities of Practice for Ecosystem Approaches \\ to Health \\ - Canada. Focus: Educational development (Canada): \\ www.copeh-canada.org \\ - Latin America and the Caribbean. Focus: Toxins: \\ http://www.insp.mx/copeh-tlac/eng/inf/index.php \\ - West and Central Africa. Focus: educational \\ development (French Africa): http://www.copes- \\ aoc.org/ \\ - Middle East and North Africa. Focus: Water \\ Resources Management: http://www.copeh- \\ mena.org/ \\ - South and South East Asia. Focus: Emerging \\ Infectious Diseases: www.copeh-ssea.org. See also \\ www.vwb-vsf.ca.
}

\section{REFERENCES}

1. Altekruse SF, Cohen ML, Swerdlow DL. Emerging Foodborne Diseases. Emerg Infect Dis.1997; 3:285-293.

2. Mahy BW, Brown CC. Emerging zoonoses: crossing the species barrier. Rev Sci Tech. 2000; 19:33-40.

3. Charron D., Waltner-Toews D., Maarouf A., Stalker M. A synopsis of known and potential diseases and parasites of humans and animals associated with climate change in Ontario. In S. Greitenhagen and T.L. Noland (comps.). A synopsis of known and potential diseases associated with climate change. On For Res Info Paper No. 154. Sault Ste. Marie: Ontario Ministry of Natural Resources; 2003.

4. Fleury M, Charron DF, Holt JD, Allen OB, Maarouf AR. A time series analysis of the relationship of ambient temperature and common bacterial enteric infections in two Canadian provinces. Int J Biometeorol. 2006; 50(6):385-91.

5. McMichael AJ. Integrating nutrition with ecology: balancing the health of humans and biosphere. Public Health Nutr. 2005; 8: 706-715.

6. Graham JP, Leibler JH, Price LB, Otte JM, Pfeiffer DU, Tiensin T, Silbergild EK. The animal-human interface and infectious disease in industrial food production: rethinking biosecurity and biocontainment. Public Health Rep. 2008; 123: 282-299

7. Weiss R, McMichael AJ. 2004. Social and environmental risk factors in the emergence of new diseases. Nat Med. 2004 (Supplement); 10: S70-S76.

8. Waltner-Toews D, Lang T. 2000. The new conceptual base for food and agricultural policy: the emerging model of links between agriculture, food, health, environment and society. Global Change and Human Health 1:116-130.

9. Hawkes C, Ruel M. The links between agriculture and health: an intersectoral opportunity to improve the health and livelihoods of the poor. Bull World Health Organ. 2006; 84: 984-990.

10. Kahn LH. Confronting zoonoses, linking human and veterinary medicine. Emerg Infect Dis . 2006; 12: 556-61.

11. Stephen C, Artsob H, Bowie WR, Drebot M, Fraser E, Leighton T, Morshed M, Ong C, Patrick D. Perspectives on emerging zoonotic disease research and capacity building in Canada. Can Vet J. 2005; 46: 65-71 
12. Schwabe CW. Veterinary Medicine and Human Health. Baltimore: Williams \& Wilkins; 1984.

13. Dobson A, Cattadori I, Holt RD, Ostfeld RS, Keesing F, Krichbaum K, Rohr JR, Perkins SE, Hudson PJ. Sacred cows and sympathetic squirrels: the importance of biological diversity to human health. PLos 2006; 3: e231

14. Gunderson, LH, Holling, CS. editors. Panarchy: understanding transformations in human and natural systems. Washington: Island Press; 2002.

15. Waltner-Toews D, Kay J, Lister N-M, editors. The Ecosystem Approach: Complexity, uncertainty, and managing for sustainability. New York: Columbia University Press; 2008.

16. Martens PM, McMichael AJ. Environmental Change, Climate and Health: issues and research methods. Cambridge: Cambridge University Press; 2002.

17. Gitau T, Gitau, M, Waltner-Toews D. Integrated Assessment of Health and Sustainability of Agroecosytems. Boca Raton:
Taylor and Francis/CRC Press; 2008.

18. Waltner-Toews D. Ecosystem Sustainability and Health. Cambridge: Cambridge University Press; 2004.

19. Parkes MW, Bienen L, Breilh J, Hsu L, McDonald M, Patz J, Rosenthal JP, Sahani M, Sleigh A, Waltner-Toews D. All hands on deck: transdisciplinary approaches to emerging infectious disease. EcoHealth 2005; 2: 258-272.

20. Arya, N, Howard, J, Isaacs, S, McCallister ML, Murphy S, Rapport D, Waltner-Toews D. Time for an ecosystem approach to public health? Lessons from two infectious disease outbreaks in Canada. Glob Public Health 2009; 4(1):31-49.

21. Funtowicz SO, Ravetz R. Uncertainty, complexity and post normal-science. Environ Toxicol Chem. 1994; 13: 1181-1885.

David Waltner-Toews: A Professor in the Department of Population Medicine at the University of Guelph, David Waltner-Toews is a veterinary epidemiologist, essayist, poet, and fiction writer. He teaches and does research on the epidemiology of food and waterborne diseases, zoonoses and ecosystem approaches to health. $\mathrm{He}$ has been co-director of the Ecosystems, Climate Change and Health Omnibus (ECCHO) Project (www.eccho.ca) and is the founding president of both Veterinarians without Borders/Vétérinaires sans Frontières - Canada (www.vwb-vsf.ca), and of the Network for Ecosystem Sustainability and Health (www.nesh.ca). He has collaborated on interdisciplinary research and teaching in Africa, Asia and Latin America. Besides being an author on about 100 peer-reviewed scholarly papers, he has published half a dozen books of poetry, an award-winning collection of short stories, a murder mystery, three books of popular science (including a natural and cultural history of zoonoses "The Chickens Fight Back", in 2007, and one on the ecological and cultural context for foodborne diseases, "Food, Sex and Salmonella", in 2008). His texts include "Ecosystem Sustainability and Health: a practical approach" (Cambridge University Press, 2004), "The Ecosystem Approach: Complexity, Uncertainty, and Managing for Sustainability" (with Nina-Marie Lister and the late James Kay, Columbia University Press, 2008), and "Integrated Assessment of Health and Sustainability of Agroecosytems" (with Thomas Gitau and Margaret Gitau, Taylor and Francis/CRC Press, 2008). 